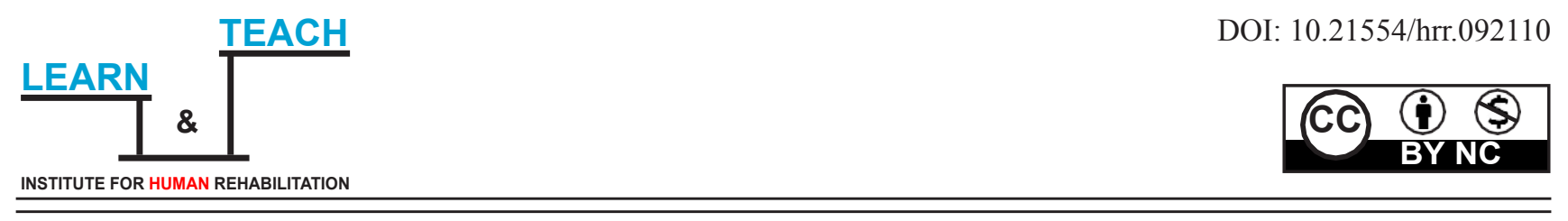

\title{
THE EFFICIENCY OF ONLINE LEARNING DURING THE COVID-19 PANDEMIC: COMPARATIVE ANALYSIS OF SOUTHEAST EUROPEAN COUNTRIES AS PARTICIPANTS IN THE NEW PATH OF EDUCATION
}

Original scientific paper

\author{
Vehbi Miftari ${ }^{1}$, Suada A. Dzogovic ${ }^{1}$, Anela Dzogovic ${ }^{1}$, Blagojka Zdravkovska-Adamova ${ }^{2}$ \\ ${ }^{1}$ University "Haxhi Zeka”, Peć/Pejë, Republic of Kosovo \\ ${ }^{2}$ South East European University, Tetovo, Republic of North Macedonia
}

Received: $2021 / 7 / 11$

Accepted: 2021/9/14

\begin{abstract}
The focus of this research is education during the coronavirus pandemic in Southeastern European countries (Kosovo, Bosnia and Herzegovina and North Macedonia). It encompasses elementary education, high schools and higher education. The aim of the research is multiple. With it, we want to present methods of distance learning during the pandemics in the above mentioned countries, challenges and advantages that have emerged, as well as potential solutions for removing faults. This is primarily qualitative research relying on several methods. We conducted interviews to understand the experiences of different stakeholders participating in the education process. This research also relies on quantitative data, i.e. researches doing by The University of Prishtina, Pedagogical Institute of Kosovo, as well as results of opinion polls and research conducted by Student Parliament and Senate of the University of Sarajevo. Their research was conducted throughout the academic year 2020/2021. Also, we compiled different texts from media, as well as statements from different stakeholders. Our method is primarily inductive - because in some cases general ideas and conclusions about distance learning in Kosovo and Bosnia and Herzegovina are based on different individual examples. Information in this research in relation to the section on North Macedonia is mainly based on three sources: Data from the website of Ministry for Education and Science of the Republic of North Macedonia; Morphosis Foundation Survey from September 2020 entitled Status and Challenges for Managing Online Teaching in Primary School; and Findings from the research with directors, teachers, and parents: Experience and Attitudes about Distance Learning, a document prepared by Reactor. Our key conclusion is that Kosovo, Bosnia and Herzegovina and North Macedonia were not an exception regarding to the problems that arose during the pandemic in terms of education, such as online teaching, adapting students to new learning conditions, training of teachers for teaching in extraordinary and new circumstances, assessment criteria, etc.

However, the situation has also brought opportunities to re-think existing education models and to find new solutions at schools and universities.

Keywords: Coronavirus pandemic, Kosovo, Bosnia and Herzegovina, Republic of North Macedonia, distance learning, scientific education, challenges, advantages
\end{abstract}

\section{INTRODUCTION}

The quality of educational institutions implies the provision of services that best meet the needs of students, academics and other participants in the education system from the immediate and wider environment, and is determined by the following criteria: achieved results of students, teaching process, running higher education institutions, as well as the connection of these institutions with its environment (Dzogovic, 2014). In this context, the appearance of COVID-19 virus in March 2020 and the pandemic it caused seriously affected all aspects of modern life, and especially the educational process throughout the world.

\section{$\overline{\text { Correspondence to: }}$}

Vehbi Miftari, Suada A. Dzogovic, University “Haxhi Zeka”, Pec/Pejë, Republic of Kosovo

E-mail:suada.dzogovic@unhz.eu,vehbi.miftari@unhz.eu 
Negative effects were observed at all levels, and the weaknesses of the education systems to cope with this process came to the surface. The lack of technology, the strict evidence of the students participating, lack of guidelines for teachers, students and parents were some of the challenges, all the institutions were facing with. That has caused sometimes in pupils, students and teachers a negative experiences and lack of willingness to participate.

'From all this we have learned a very important lesson, i.e. that in the 21st century it is impossible to function without online activities. At the local and global level, education must be adapted to the world trends for this type of teaching and we should all work in overcoming the problems that have arisen during this period' (Zdravkovska-Adamova \& Taneska, 2020). So far, the pandemic has challenged us and our democratic system (Zimmerman, 2020).

The coronavirus pandemic and distance learning are challenges that the world is still going through. We are writing this article at the point when we still do not have a meta-narrative about such phenomena. In this paper, we are focusing on the way schools and universities in Kosovo, Bosnia and Herzegovina and North Macedonia coped with these issues. Hence, we can analyze and observe these problems with current temporal and spatial limitations. At this point, it is impossible to predict and analyze the long-term impacts of distance learning on pupils and students, their social skills, or psychological state. Neither we can at this stage compare successes and failures of distance learning in the USA, Germany, France and the Balkans, nor can we discuss relevant measurable data about it. We cannot bring such conclusions for several reasons. Firstly, governments tend to combine normal teaching methods with online schools and switch from one to the other depending on the current epidemiological situation. Secondly, students encountered distance learning only partially during their education. Hence, these results are not yet fully measurable and comparable. Nevertheless, these temporal and spatial limitations should not be the reason to leave this topic unexplored altogether.

Methods and sources that we have extensively relied on - such as media reports and interviews, help us understand first-hand experiences with main stakeholders in the education process in Kosovo, Bosnia and Herzegovina and North Macedonia. We spoke to all relevant participants in the education process, primarily with the Rector of the University of Sarajevo, Vice-Rector of the University of Prishtina, in Kosovo, university professors, assistants, high school principals, as well as representatives of the Student Parliament, to fully understand and comprehend the impact of distance learning on pupils, students, teachers, parents, professors, officials and decisionmakers. Lastly, we should bear in mind that human beings are at the center of the education process and hence it is their voices that matter the most.

The coronavirus pandemic has brought unexpected challenges and changes for education systems around the globe.
Different governments were faced with increased infection and death rates and hence were forced to impose lockdowns that affected kindergartens, schools and universities.

Kosovo has taken few steps to organize the distance learning soon after the pandemic was officially announced. This measures has been oriented in three directions: to organize the distance learning; develop documents for implementing the distance learning and manage the distance learning (Mehmeti, 2020).

Bosnia and Herzegovina is a country with a very complex administrative and political system. Hence, it had unique challenges. We are talking about the country with fourteen governments, two entities, one district and ten cantons in the Federation of Bosnia and Herzegovina. All these governments have often brought different and conflicting decisions and coronavirus pandemic is not an exception in that regard. Education is not an exemption. Each government level has often brought its own decisions, often without coordination with other levels of government, which was very often confusing for citizens. For example, at the very beginning of the corona crisis, children were allowed to move freely in Republika Srpska, while Federation of Bosnia and Herzegovina put the ban on free movement for those under eighteen. It caused many problems for people living around the inter-entity boundary line. There were literally examples of streets with different rules and regulations. People living in Sarajevo faced another problem when they wanted to spend time on the local mountain Trebevic, as they were forced to move through the inter-entity boundary line to get there and face potential fees accordingly.

The same applies to education during the pandemic. We are talking about a country without a unique education system on the state level. There is no state ministry of education like in many other countries around the globe. Entities and cantons in Federation Bosnia and Herzegovina are in charge of education instead. That implies that every canton decides whether schools will be closed or not. The same applies to universities which decide whether they will introduce distance learning depending on epidemiological situation and measures such as bans on public gatherings etc. Like everywhere else in the world, schools and universities in Bosnia and Herzegovina faced an unprecedented situation and they were forced to change traditional learning models. Entity Republika Srpska was the first to decide to close schools and universities and introduce distance learning in March 2020. The same happened in other parts of the country while the epidemiological situation became worse. Republika Srpska started broadcasting lessons on public broadcaster RTRS for lower grades, which is still in force. A teacher would record a lesson which is broadcasted in the morning. Children and parents were in contact with teachers, while older pupils used the online model. The entity Federation of Bosnia and Herzegovina did not introduce systematic and unique distance learning through public broadcasters. However, there were some initiatives and attempts. 
This entity and its ten cantons introduced online learning. However, problems have emerged in the very beginning. Public broadcasters are another complicated problem in Bosnia and Herzegovina. The country has, as earlier explained, a very complicated administrative system and different layers of government. It does not have a unique policy regarding public broadcasters and TV content. The state one - National public television channel BHRT [Radio and Television of Bosnia and Herzegovina] could not satisfy the needs of three ethnic groups in the country, i.e. three narratives and education policies. It is practically impossible since education policies are created by entities and cantons. The National public television channel BHRT did have some attempts to introduce distance learning. However, their content was focused only on science, physics, mathematics and avoided social sciences, history and language that are subjects of different ideologies in the country. There were also some attempts on the federal level, as well as cantonal. Journalist of Al Jazeera Balkans Aida Hadzimusic did research on that topic and she concluded it is practically impossible. Firstly, there are ten cantons in Federation Bosnia and Herzegovina and not all of them have their own public broadcaster. Secondly, even cantons that have their own broadcaster do not necessarily have funds for such an endeavor. In Republika Srpska, it is much simpler, as the entity has a centralized system unlike Federation Bosnia and Herzegovina. Government officials from the Bosnian-Podrinja Canton Gorazde told Al Jazeera Balkans that they do not have a budget for that. In Una-Sana Canton, in the northwestern part of the country, there were some attempts. The core of the problem lays in the fact that governments brought ad hoc decisions and improvised solutions, without coordination on the state level - which would have been impossible, because of the complexity of the state.

In the Republic of North Macedonia there is a Ministry of Education and Science (MES) which is responsible and competent for the overall education in the country, ie according to the official website of the Government (MES, 2020) for:

- upbringing and education of all types and degrees;

- organization, financing, development and promotion of upbringing, education and science;

- the upbringing and education of the children of our workers on temporary work and residence abroad;

- verification of professions and profiles in education;

- $\quad$ the student standard;

- technological development, informatics and technical culture;

- information system;

- international scientific-technical cooperation;

- the supervision within its competence and performs other activities determined by law.

The emerging situation imposed by the pandemic posed a major challenge to the relevant ministry responsible for dealing with problems in the education process.
From March 11, 2020, the teaching was completely online, and the new school year from September 2021 for first to third grade pupils in primary schools was with a physical presence or online, according to the parents' choice, and from fourth grade onwards only distances learning.

\section{EQUIPMENT}

The transition from physical to distance learning in schools requires, above all, possession of adequate equipment - laptops, tablets, or at least a decent smartphone.

In the nearby country, Albania, more than $90 \%$ of the students, teachers or parents did use their mobile phones instead of using lap-tops or PCs (Osdautaj, 2020).

Digital competence has been very limited, $42 \%$ of the teachers and school directors in Kosovo didn't follow any training program for using new technologies in distance learning (Pedagogical Institute of Kosovo, 2020).

However, that basic requirement was a challenge for parents as well in Bosnia, especially at the very beginning, even for the most developed part of the country like Canton Sarajevo or capital city of North Macedonia. Canton Sarajevo is the canton with the largest budget in the country. The state's capital - Sarajevo is its part with the most developed municipality in Federation Bosnia and Herzegovina, according to relevant state institutions. Given all the above, one would expect that problems with equipment will be minimal. However, they emerged. The canton also faced several changes of government since the 2018 general elections. Anis Krivic of the SBB (Stranka za bolju budućnost) [Party for a Better Future] was part of a no-confidence motion on November 30 , 2020. The mandate was taken over by Naida HotaMuminovic, who previously commented on the experiences of online teaching for the purposes of this research in her capacity as the director of the First Bosniak Gymnasium. As Anis Krivic, former Cantonal Minister for Education said, problems emerged at the very beginning of the pandemics: 'We had nearly 500 children without laptops, tablets or smartphones', said Krivic for Al Jazeera Balkans (Al Jazeera Balkans, 2020).

The problem was even more apparent in rural areas. According to the Institute for Youth Development, around 1000 children in 44 local communities could not attend school online because they did not have the necessary equipment. There are 143 local communities in Bosnia and Herzegovina and research of the Institute for Youth Development encompassed only a third. (Here, too, the complexity of the state apparatus should be borne in mind; part of the local communities are in the entity of Republika Srpska and they enter the domain of research of the competent institutions there, while the local communities in the Federation of Bosnia and Herzegovina are distributed in the cantons. 
Certainly, the research of the Institute for Youth Development is useful to illustrate the general situation when it comes to having the necessary distance learning equipment.) The problem was mainly solved thanks to non-governmental organizations, humanitarian organizations and their donations. Parent Council in Canton Sarajevo made sure to provide laptops and tablets for children from poorer families. Hence, the pandemic has brought to the surface already existing problems, especially when it comes to equipment and social inequalities.

There are similar problems in terms of technical equipment in North Macedonia. Existing economic differences became even more pronounced during the pandemic, but this time they also affected the quality of education. 'Unfortunately, in the Republic of North Macedonia there are still schools in which the internet access is inadequate, and the ICT infrastructure is in poor condition or does not exist at all. This situation, as well as the very poor economic situation of the families, has led to a number of pupils ${ }^{1}$ not being able to attend classes online at all' (Метаморфозис [Metamorphozis], 2020).

An additional problem is that the teachers had to switch to a completely different way of teaching in one day, for which they were usually not sufficiently trained. On the other hand, the problem is their technical equipment, i.e. 'More than half of the teachers have limited access to equipment for distance learning - a significant part share a computer or laptop with other family members or use obsolete machines, and a small percentage do not have in general. An additional significant proportion (42\%) have internet problems or it is limited' (Реактор [Reactor], 2020).

\section{MONITORING ISSUES}

Parents who work were faced with additional problem, as well as people with kids of different ages and school tasks. Some parents continued to go to work and students - whether in primary or secondary school, would be left to fend for themselves.

Around $30 \%$ of the parents in Kosovo have declared that they are facing with difficulties during the distance learning, utilizing new technologies (Mehmeti et al., 2020).

In other cases, parents would work from home and, in addition to their regular responsibilities, would be referred to the necessary assistance to children and motivate children to work. A problem has arisen and it is equipped in households where several children of different ages have to attend classes at the same time, with only one available tablet or laptop. Here is how the mother of three boys, elementary school students from Zenica, commented on the situation: 'I had to neglect my own obligations as a housewife and I would really love my children to go back to school', said Aida Telalovic for Al Jazeera Balkans (Al Jazeera Balkans, 2020).
The situation is similar in North Macedonia. According to the research of Reactor (Реактор [Reactor], 2020), in this regard there are 2 key problems for parents:

- Due to work responsibilities they do not have enough time to devote to learning with the child/children.

- For some subjects they have difficulty with lessons to help the child/children.

\section{CURRICULA AND THE IMPACT OF REMOTE LEARNING ON SOCIALIZATION}

Parents Council in Canton Sarajevo addressed the problem of grading method in online learning and that issue applies to the rest of the country as well. The Council wanted the Ministry of Education to modify existing assessment methodology and to give new instructions on the assessment applicable to online and distance learning. Even before the coronavirus pandemic, Canton Sarajevo has been introducing an 'online week', when pupils get used to distance learning models. The rest of the country was forced to apply the same pattern when governments decided to close schools. Parents in Canton Sarajevo wanted an adequate way of grading. They wanted grades at the end of the year not to be lower than the one in the midterm. They also requested classes not to be longer than 30 minutes. The country simply did not have curricula fully applicable to online and distance learning, despite short 'online school' programs introduced by the Canton Sarajevo earlier. Full adaptation to distance learning form would require long-term endeavor including experts, professors, ministry, etc. The director of the elementary school in Zenica said it was very hard for his school to adapt to new circumstances. An advocate of a return to schools said: 'Our curricula are based on traditional learning models in classrooms, not online teaching. Children belong to schools', Murat Spahic said for Al Jazeera Balkans (Al Jazeera Balkans, 2020). Institutions that have digitalized their services and that have already introduced modern learning methods were not an exception. The First Bosniak Gymnasium - one of the best schools in Sarajevo. The school was awarded the prestigious Sixth April Reward of Sarajevo and it is also home to Cambridge international school where classes are taught in English. The former director of that educational institution, Naida Hota-Mumimovic, pointed out for this research the problems that arose in the process:

'The most significant changes happen in the sphere of knowledge assessment. That was the most apparent paradigm shift. Schools were always places of socialization. However, students are not able to socialize, which creates emptiness. When at school, children are exposed to different processes that strongly influence personality development. Unfortunately, these processes were minimized during the pandemic', said Hota-Muminovic (Hota-Mumimovic, 2020, personal communication, 3 December).

${ }^{1}$ According to The Concept for Distance Education the latest data provided during the COVID-19 crisis show that around 30,000 pupils (from vulnerable categories) do not have an IT device at home (MES, 2020). 
(Naida Hota-Muminovic participated in this research as director of the First Bosniak Gymnasium. After the government fell for the second time from general elections in 2018, she became Minister for Elementary and Secondary education. The Ministry for Education, Science, Culture and Sports split into two - one for Elementary and Secondary education and another for University education).

Online teaching has encouraged reflection on changes in the system. Authorities saw the need for legal changes. In the Sarajevo Canton, amendments to the Law on Primary Education were adopted, which were initiated in order to simplify the procedures for deciding on the manner of teaching. According to the former minister, this will in the future facilitate the transition from classroom to online teaching in the case of a declaration of a state of natural disaster. Amendments to the law also specify the number of classes that students from 4th to 9th grade of primary school can do in one day or week.

In North Macedonia, the Ministry of Education and Science adopted instructions for changing the curricula, ie for shortening them. The school year 2020-2021 started one month later, ie on October 1, 2020. The duration of the 45-minute the class was reduced to 30 minutes in primary schools and to 35 minutes in secondary schools. At the same time, care has been taken to base the shortened curricula on the learning objectives/results provided by the curriculum for each subject. The main problem that teachers face is that they do not have clear assessment guidelines for online teaching.

\section{CHALLENGES FOR STUDENTS AND PROFESSORS}

The increased infection rates in Bosnia and Herzegovina also affected students at universities. At the very beginning of corona crisis, the authorities decided to provide additional accommodation capacities for COVID-19 patients. They feared that hospitals will be overburdened and decided to use faculties for additional accommodation. In May 2020, Sarajevo Canton decided to use Faculty of Architecture and Faculty of Civil Engineering as hospitals. Additionally, the student dormitory was set up as an isolation camp for people returning to Bosnia and Herzegovina from abroad. However, it did not mean that the crisis management was successful. On the contrary, money was spent in vain, because faculties were never used as isolation centers or hospitals. The dormitory functioned as an isolation ward for a very short time. People who stayed there had numerous objections.

With the closure of primary and secondary schools, faculties also switched to the distance learning model, which prompted necessary legal changes in the field of university education.

In early October, the Assembly of Canton Sarajevo adopted Amendments to the Law on Higher Education. Students in Canton Sarajevo insisted on new regulations before the start of the academic year 2020/2021.
Several changes requested by students were eventually adopted by the ministry. Authorities enabled students to get additional exam terms and to take exams that were not organized due to the pandemic. Students also demanded new teaching processes and exams applicable to distance learning models and the formal treatment i.e. recognition of online learning. 'They were enabled to enroll in the academic year 2020/2021 without some requirements applicable to circumstances before the pandemic. Paying tuition fees in three installments was also among accepted changes' (MONKS, 2020).

However, these law amendments satisfied the needs of students only partially, as the president of the Student's parliament of the University of Sarajevo Faruk Devic explained to us. Student's parliament of University of Sarajevo conducted opinion polls of nearly 1000 students to understand their satisfaction with online learning. Results showed that most students were not satisfied with the way classes were organized.

'The coronavirus pandemic has brought many challenges for students and professors, in terms of material and legal challenges. Considering the former one, there were no adequate platforms and applications for online learning. Only a few faculties managed to swiftly switch to new learning models. Professors were also very slow in their adaptation to the online model. Many improvised in their attempts to teach online. Others believed it was enough to simply send materials and presentations without teaching and explaining the content. Student's parliament of the University of Sarajevo was very proactive in that regard-demanding teaching, activities and online consultations to foster interaction between students and professors like before the coronavirus pandemics', said Devic (Devic, 2020, personal communication, 4 December).

Socialization during the university is important, but it is not the key segment like in early elementary education and in high school. We assume that more-less completed personalities enroll in the faculty - people who already have a wider circle of acquaintances and friends made in earlier stages of life - from the neighborhood, primary and secondary schools and the like. However, the transition to distance learning has brought challenges for both students and professors. For the purpose of this research, we spoke to Mirjana Mavrak, professor at the Department of Pedagogy at the Faculty of Philosophy of the University of Sarajevo. We believe it was important to speak to pedagogy professors because they are the ones who educate future teachers who will continue to actively participate in educational processes. Mavrak is an expert in adult education, microandgragogy, counseling and therapeutic work, traumatic psychology, communication and the like.

Mavrak explained which technology she used in online teaching:

'I use two platforms. One of them is BISER available at the Faculty of Philosophy from 2009 and ZOOM. BISER enables me to create folders with subjects that I teach. Students can leave materials there, I can post tasks, tutorials, etc. 
However, there are too many students attending classes, we do not always have the best internet connection. Hence, I use ZOOM for teaching and talking to my students. It is impossible to control the presence of students, which is something that I have never done before. Just like before the pandemics, I record only active students, without punishing absence. I have also changed the concept of my lessons - I write plenty of essays instead of simply posting Power Point Presentations, so that students can have a better understanding. They read texts during the classes and then we discuss main issues. I create simple questions to check understanding and my exams usually consist of an open-book test. For me, it very stressful and timeconsuming. It takes three to four times more to prepare than in normal circumstances. However, the most difficult thing for me is lack of non-verbal contact with participants' (Mavrak, 2020, personal communication, 4 December).

As Mavrak explained, problems emerged with personal communication and understanding with students who were happy with distance learning only at the very beginning of the pandemic: "At the end of last semester, they were exhausted by the amount of homework in different subjects. They were eager to physically meet in class. I believe that the combination of in-class and online teaching (hybrid model) would be the most appropriate solution. Our guidelines are simply not good enough to provide a smooth transition from inclass to online teaching. Unfortunately, many from the academic community believe it is the simplest linear transition - the replacement of voice and physical presence with a microphone and scanned texts. But that is not it. We do not live distance learning; it is only a transitional solution suitable for the current crisis. We need a true alternative to in-class teaching which requires a lot of commitment' (Mavrak, 2020, personal communication, 4 December).

Lastly, without being overly pessimistic, Mavrak also underlined some advantages of distance learning: 'The great advantage lays in the fact that we have erased spatial boundaries and the fact that we have converted them into temporal ones. It is possible to schedule a meeting with students when they are available and we do not have to reserve spaces at the faculty anymore. We do not have to squeeze in hallways and we can literally meet anywhere and from anywhere. We are able to take full responsibility for the process that we lead. We can have deeper contacts between different disciplines. Nowadays, IT (i.e. IT professional) is very important for us. The disadvantage lays in the fact that some are unwilling to change the paradigm of teaching, education, the role of teachers, learning outcomes. Professors refuse to re-think their role and to talk to each other in the process. They do not discuss whether students are overwhelmed, and if they do, they do it without serious professional involvement. Authorities in the Ministry of Education are completely unaware of an ongoing process. They rely on shallow assessments of referees and friends, which can be dangerous when it comes to professional engagement.
I believe that we need deep andragogical approach and education of professors in three aspects: online content, online-student and I-online, as well as improvements of the content itself' (Mavrak, 2020, personal communication, 4 December).

\section{DISTANCE LEARNING FROM THE PERSPECTIVE OF UNIVERSITY MANAGEMENT}

For the purpose of this research, we also talked to the Rector of the University of Sarajevo - Mr. Rifat Skrijelj, who explained to us how the university management sees online education and how different faculties within University of Sarajevo managed to cope with the crisis (due to the epidemiological situation, the answers were made in consultation with the Department of Teaching and Student Affairs and delivered to us by e-mail).

In line with the epidemiological situation, the Senate of the University of Sarajevo decided to switch to distance learning on March 11, 2020.The Department of Academic and Student Affairs conducted a research about the results of online learning. It encompassed twenty faculties of the University of Sarajevo (The Senate decided that the University should continue with distance learning on March 23. They also enabled students to attend online exams in April term for students that had enrolled before the Bologna Process was introduced, as well as students who enrolled during the Bologna Process). Each faculty submitted their results and information explaining which platforms they used, as well as problems and needs that arose throughout. In line with the results that the head of Academic and Students Affairs submitted to us, we can say that most problems were related to technical limitations. Most faculties did not have adequate or enough equipment, internet connection was often slow, platforms were overloaded, etc. An online model was simply not an adequate replacement for physical presence. Even if it was a good solution, the equipment available was not modern or sophisticated enough. Academy of Music provided the following answer:

'The professor/assistant cannot have full and complete insight into student's work and results online. It is impossible to assess the quality of hand or finger positions on instruments, etc., not to mention acoustic elements that are different in vivo and online. Another important issue is the quality of microphones, speakers etc. Music education has been established throughout centuries and it requires constant and intensive live interaction between students and teachers' (Academy of Music, University of Sarajevo, 2020, e-mail, January 13).

They also explained that there are some subjects, where it is practically impossible to organize classes such as choir, orchestra and conducting.

The Faculty for Natural, mathematical and biotechnical scienceswas not able to conduct laboratory experiments. Furthermore, scanned materials that professors were sending to their students were large in size which hindered distribution. 
The faculty also faced the lack of digital equipment, necessary to record the content. The staff demanded new equipment - computers and digital cameras. The faculty of Veterinary Medicine staff said that they were also unable to conduct practical lessons and that they would partially solve the problem with the purchase of new computers with adequate audio-visual equipment and web cameras. The Faculty of Civil Engineering was unable to conduct mid-term exams. Some students at the Faculty of Pharmacy did not have computers and a good internet connection. They said that they needed new laptops, TVs and a virtual lab. Many professors at the Faculty of Electrical Engineering did not have adequate recording equipment, drawing boards and cameras. They also said that they needed a license for professional software, as well as a license for Zoom platform. Zoom enables meetings up to 40 minutes, which was a problem for the staff at the Faculty of Sports and Physical Education. The Faculty of Architecturedid not have equipment for digital drawing. They demanded 'All-in-one' computers/laptops, systems for video conferences and smart boards, headphones with microphones etc. The Academy of Performing Arts staff was unable to perform lessons on subjects such as Acting, Speech, Dance, Physical training, Puppetry, etc. Additionally, students did not have an appropriate internet connection. Professors said that online classes by international lecturers would be very useful. The Faculty of Medicine did not submit their data, which would have been very useful for this research.

However, even faculties with dominantly theoretical lessons, where a physical presence is not a must, faced problems. The staff at the Faculty of Economics and Business said that their faced technical issues when there were too many students using the system at the same time. Around 500 use Moodle and BigBlueButton simultaneously and hinder the stability of the system. They said that they would need a faster internet connection and a license for 'Respondus' - system for knowledge assessment based on artificial intelligence.

Some professors at the Faculty of political sciences did not have the necessary equipment to work remotely. The faculty lacked technical support; it has only one IT expert, which is insufficient even in normal circumstances. They said that they could not post books online, because of copyright issues and rights and that they needed web cameras, speakers, laptops, and IT support. Many faculties - the Faculty of Pedagogy among them would need to educate their staff to use platforms for online teaching. Feedback from each one of twenty faculties was useful and generally speaking, problems are mostly related to poor equipment, professors with lack of technical knowledge, inability to conduct practical lessons. Accordingly, needs were also focused on these issues.

Some statistical data gathered by the Senate of the University of Sarajevo is also worth presenting. The results show that in most cases the classes were conducted with a full fund of hours - namely, in 1358 cases. Classes were shortened in 362 cases and canceled in 107 cases.
In most cases (1762), professors made materials available for distance learning, they did it partially in 215 cases. In 48 cases, professors did not provide materials.

Materials were mostly useful to students (1658 cases), partially useful 295 cases and useless in 68 cases.

Data gathered by the Senate of the University of Sarajevo also show which platforms were the most common: ZOOM (421 cases), Office 365 Microsoft Teams (284), Big Blue Button (261), Google Classroom (223), Skype (34) and Jitsi Meets (7).

In most cases (1419), professors were available for consultations with students by e-mail. In 68 cases, they were not available.

Technical problems during online classes were recorded in 57 cases, partial problems in 742 cases. In 1054 cases, problems were not recorded.

Results regarding the presence of students are the following: In most cases, students attended lessons in a capacity of more than $70 \%$, in 260 cases they attended lessons in a capacity between $50 \%$ and $70 \%$. In $60 \%$ cases, they attended in a capacity less than $50 \%$.

Students were also able to rate the successfulness of distance learning from 1 to 5 , whereby 1 means the worst, while 5 means the best grade. Most students (1009) wrote number 4; number 5 was written in 524 cases, number 3 in 169 cases, number two in 73 cases, while 34 students wrote the lowest grade - one. In 1539 cases, students had a positive attitude towards distance learning, a negative attitude in 399 cases, while 18 students did not have an attitude.

During the academic year 2020/2021, 1865 exams were held online and 611 in person.

We also talked to the rector of the University of Sarajevo and asked him whether he believes that the coronavirus pandemic had negatively affected students in terms of knowledge. Skrijelj said he believed that students were affected in terms of social interactions and creative learning:

'I believe that education is one of the key foundations of our community. Teachers should not limit themselves to the traditional transfer of knowledge anymore the one where the professor says what he has during the class, and then simply recommends books for exams. That belongs to the past. We need to follow the direction of transformative pedagogy that promotes the joint transformation of students and teachers. Education takes place in the community and cannot be perceived outside it. We do not train candidates in a vacuum. Rather, we prepare them for work in the real environment - that should be the purpose of our call. What is crucial is the question of freedom, in the sense of Freir's study of the pedagogy of the disenfranchised where the emphasis is on education as a practice of freedom, where all people are critical and where they creatively change the world in which they live. We must train our students to forester dialogue. We need to prevent the human from self-delusion by focusing on himself only. Practically speaking, our students should complete their education aware that traditional teaching models belong to history. 
Such models imply a simple bias - that the professor is the one who knows everything, that students are to be taught and that they are ignorant. Students should be aware that dialogue is a key. Thereby, a traditional relations professor-student; student-professor fades out. New opportunities open for all stakeholders. Both sides simultaneously learn and teach. A professor is not the one who simply teaches; he also learns through a dialogue with students who also become teachers. Both sides become responsible for the process which means growth for everyone' (Skrijelj, 2020, personal communication, 14 January)

The Senate of the University of Sarajevo also stated that it is very useful when colleagues exchange experiences regarding new practices when it comes to learning and teaching. Therefore, the University of Sarajevo organized webinars, where teachers exchanged experiences on their practices during the COVID-19 pandemic. The title of the first lecture"Do we want to consciously change - what kind of teaching do students want after a pandemic?" was very interesting in that regard. According to the Senate, the lecturer Melisa Okicic from the English Language Department at the Faculty of Philosophy in Sarajevo offered useful solutions that might offer answers to some of the problems. These solutions include a systematic examination of students' needs and attitudes regarding distance learning, examining needs of teachers, as well as their perceptions of competence and readiness for distance learning, the establishment of a single Learning Management System, establishing secure, reliable and valid Student Achievement and Evaluation System, and activating the Teacher Support Center and launching teaching and learning in an online environment. It was emphasized that it is important to adapt learning and teaching processes for generations who feel that the virtual world is their natural environment.

In that regard, it is also worth mentioning that even such professors faced challenges in the process. We talked to Anes Osmic - an assistant at the Bosnian Language and Literature Department at the Faculty of Philosophy in Sarajevo. Osmic has recently graduated himself, he was born in 1990 and we can say that the internet is a natural environment. However, Osmic said it was also hard for him to conduct lessons and work with students:

'I need to admit that remote learning was a challenge for me as well. I found it hard to connect with students, which was much easier when they were physically present. For instance, some of them were unwilling to turn their cameras on and I was unable to see their facial expressions - often useful for my assessment of their interest and level of their participation. Generally, we lack regulations about online teaching, almost a year after authorities introduced it. I would like to know and understand details regarding the whole online system - whether I can request students to turn their cameras on, which platform is best to use and why, what are advantages and disadvantages, etc. There are even more questions that none was properly answered so far.
I do not have the impression that there were some serious discussions in that particular context. Teachers are left to struggle themselves, they are left to their own resources, capacities, creativity and awareness', Osmic said (Osmic, 2021, personal communication, 18 January).

\section{SEEU IN THE PERIOD OF THE PANDEMIC CAUSED BY THE COVID-19 VIRUS}

The South East European University (SEEU) is a public non-profit university in North Macedonia that is making steady progress, and confirmation of this is certainly the relevant rankings of higher education institutions in the country, according to which it is in one of the leading positions.

The studies take place on both campuses, one in Tetovo, widely known for its impressive ambiance, and the other in Skopje, at the site that connects the old and new parts of the capital.

Apart from the exceptionally high quality higher education, which is in line with modern world trends, many aspects make it unique.

We will try to list the most important ones. It has modernly equipped dormitories, extremely rich libraries, access to the richest online resources is provided.

Every student is important to the University. Therefore, special attention is paid to the personalized approach. Digitalization is at the highest level, striving to be in line with the constant progress in this field. In that regard, we will emphasize that in just one day, in conditions of a pandemic, we switched from physical presence to online teaching. 'The South East European University (SEEU) was previously known as a leader in the country, but also in the region in terms of commitment to digitalization in every segment of its functioning, and especially in teaching activities. Therefore, it was not a problem to make a transfer in a single day - from teaching in the classroom, to continue with online teaching on March 11, 2020. Confirmation of the quality of the realization of the teaching process in the period of the pandemic is the high grades of the students assigned through the anonymous evaluation. The well-established Google Meet and Google Classroom platforms have proven to be a solid foundation for teaching in extraordinary circumstances. However, the knowledge gained in the period of online teaching clearly indicates the possible shortcomings that need to be addressed in the future. What stands out as a problem is the awareness of some students for active participation in the whole process, but also for its benefits. Some students during the teaching process faced technical problems (poor internet, lack of computer, etc.)' (ZdravkovskaAdamova \& Taneska, 2020).

The academic year 2020-2021 started with a hybrid regime, i.e. with the offer of teaching with physical presence and online. The University was fully prepared for the implementation of teaching in accordance with all safety protocols, and the quality of teaching was at the highest level. 
The teaching staff was ready to adapt the learning process from conventional teaching to distance learning. This change was accepted as a way of upgrading capacity, responding to global needs for new forms and ways of learning.

However, due to the fact that the academic staff and students are aware that the conventional way of learning, SEEU was the only university that in the past academic year organized classes with a physical presence, respecting the strictest safety protocols.

\section{CONCLUSION}

While speaking about education policies in August 2020, UN Secretary-General Antonio Guterres strongly advocated a return to schools. He said that they should be opened with all necessary protection measures, warning of the generational catastrophe the world faces. He claimed that the corona crisis left out many - minority groups, children with disabilities, children from poor families, and he appealed for an increase in the budget for education (Al Jazeera Balkans, 2020). Regarding Bosnia and Herzegovina, we can say that all the global challenges are applicable to that country as well. Changing environments, the transition to distance learning, lack of adequate equipment, the emergence of existing social inequalities, the negative impact on socialization and legal challenges - all was brought to light with the coronavirus pandemic. The response of Bosnian authorities is hard to assess at this stage. However, we can say with certainty that the corona virus made all these issues visible - at the social level, but also in terms of the education system. Lack of equipment is a problem addressed mainly by NGOs and humanitarian organizations. The education of teachers and university professors is something that cannot be carried out overnight. Each household had its own issues when it comes to all these challenges. However, we can speak about minor positive changes, especially when it comes to law and regulation changes. In Sarajevo Canton, which we cited as an example, they were designed to legitimize a learning model that was only possible and acceptable during the pandemic. In conclusion, these are small, but at this point perhaps the only possible steps. The impact of the whole situation on the quality of education is something that will need to be considered at a time when there is a meta-narrative about this specific historical moment that we live in.

According to the analysis, it can be concluded that two countries are facing similar problems. However, it is also important that we have gained significant experience in the past period.

The opinion of the experts is that online lectures are significantly different from traditional teaching. Despite the different advantages, when it comes to the quality of lectures, our opinion is that it is still on the side of teaching in the classroom. On the other hand, the new circumstances have proved to be an excellent basis for serious work to improve online teaching.

\section{REFERENCES}

Al Jazeera Balkans. (2020). Guterres: Prijeti generacijska katastrofa, djeca ne idu u školu [Guterres: A generational catastrophe threatens, children do not go to school]. Available at: http://balkans.aljazeera.net/vijesti/guterresprijeti-generacijska-katastrofa-djeca-ne-idu-u-skolu (Accessed: 4 December 2020).

Al Jazeera Balkans. (2020). Nastava na ekranu, različiti program javnih službi u BiH [On-screen teaching, various public service programs in $\mathrm{B} \& \mathrm{H}$ ] [Video]. Available at: https:// balkans.aljazeera.net/videos/2020/3/17/nastava-na-ekranurazliciti-programi-javnih-servisa-u-bih (Accessed: 20 June 2021).

Al Jazeera Balkans. (2020). U BiH još nema odluke o povratku u škole [There is no decision on returning to schools in B\&H yet]. Available at: http://balkans.aljazeera.net/video/ubih-jos-nema-odluke-o-povratku-u-skole?qt-video_wide_ tabs $=1$ (Accessed: 4 December 2020).

Dzogovic, A. S. (2014). Politički i obrazovni procesi Bošnjaka Kosova (nedostaci i moguće perspektive) [Political and educational processes of Kosovo Bosniaks (shortcomings and possible perspectives)]. Univerzitetska hronika: časopis Univerziteta u Travniku (11), pp. 91-99.

Instituti Pedagogjik i Kosoves [Pedagogical Institute of Kosovo], Mësimi në distancë - E-mësimi në arsimin parauniversitar në Kosovë në rrethanat e krijuara nga pandemia Cocid-19 [Distance Learning - E-Learning in Preuniversity Education in Kosovo during the Pandemic Covid-19], Prishtina, Kosovo, May 2020.

Mehmeti et al. (2020). Krahasimi i rezultateve dhe diskutimi i tyre [Comparison of results and their discussion], in: 'Distance Learning - E-Learning in Preuniversity Education in Kosovo during the Pandemic Covid-19". Pedagogical Institute of Kosovo, pp. 249-269.

Mehmeti, S. (2020). Mësimi në distancë/E-mësimi në arsimin parauniversitar në Kosovë [Distance Learning/E-Learning in Preuniversity Education in Kosovo], in: 'Distance Learning - E-Learning in Preuniversity Education in Kosovo during the Pandemic Covid-19". Pedagogical Institute of Kosovo, pp. 57-74.

Метаморфозис - Фондација за интернет и општество [Metamorphozis - Fondation for Internet and Society]. (2020). Состојбите и предизвиците за спроведување онлајн настава во основните училишта [Situation and challenges of managing online primary school teaching]. Available at: https://metamorphosis.org.mk/wp-content/uploads/2020/09/ oor_istrazuvanje_2020.pdf(Accessed: 2 February 2021).

Ministarstvo za obrazovanje, nauku i mlade Kantona Sarajevo [MONKS] [Ministry of Education, Science and Youth of Sarajevo Canton]. (2020). Rok za primjenu Zakona o udžbenicima produžen, pojednostavljene procedure donošenja odluka o načinu izvođenja nastave [Deadline for application of the Law on Textbooks extended, simplified decision-making procedures on the mode of teaching]. Available at: https://mon.ks.gov.ba/aktuelno/novosti-savlade/rok-za-primjenu-zakona-o-udzbenicima-produzenpojednostavljene-procedure (Accessed: 4 December 2020).

Ministarstvo za obrazovanje, nauku i mlade Kantona Sarajevo [MONKS] [Ministry of Education, Science and Youth of Sarajevo Canton]. (2020). Skupština KS po skraćenom postupku usvojila izmjene $i$ dopune Zakona o visokom obrazovanju [The Assembly of SC [Sarajevo Canton] adopted the Amendments to the Law on Higher Education by abbreviated procedure]. Available at: https://mon.ks.gov. ba/aktuelno/novosti-sa-vlade/skupstina-ks-po-skracenompostupku-usvojila-izmjene-i-dopune-zakona-o (Accessed: 4 December 2020).

Министерство за образование и наука [MES] [Ministry of Education and Science]. (2021). Соопштенија [Press release]. Available at: https://vlada.mk/MO (Accessed: 15 June 2021) 
Minstria e Arsimit, Shkencës dhe Teknologjisë së Kosovës [Ministry of Education, Sciences and Technology of Kosovo], Detyrat dhe pergjegjesite per realizimin e mesimit ne distance [Duties and responsibilities for the realization of distance learning]. Available at: https://masht.rksgov.net/uploads/2020/03/detyrat-dhe-pergjegjesite-perrealizimin-e-mesimit-ne-distance-mashti_1.pdf (Accessed: 10 July 2021)

Osdautaj, M. (2020). Ecuria e zhvillimit të mësimit në distancë në disa vende të BE-së dhe në vendet e Ballkanit [Distance Learning Development in some of the EU countries and SEE countries], in: 'Distance Learning - E-Learning in Preuniversity Education in Kosovo during the Pandemic Covid-19”). Pedagogical Institute of Kosovo, pp. 75-101.

Реактор [Reactor]. (2020). Искуства и ставови во врска со учењето на далечина [Experience and Attitudes about Distance Learning]. Available at: https://www.unicef.org/ northmacedonia/media/6881/file (Accessed: 4 December 2020).
Zdravkovska-Adamova, B. \& Taneska, P. A. (2020). Development of Critical Thinking Skills for Macedonian Language for Professional Purposes 2 During the Online Teaching Period. SEEU Review, 15(1), pp. 60-70, https://content.sciendo. com/view/journals/seeur/15/1/articlep60xml (Accessed: 4 December 2020)

Zimmerman, J. (2020). Coronavirus and the Great Online-Learning Experiment, The Chronicle of Higher Education. Available at: https://www.chronicle.com/article/coronavirus-andthe-great-online-learning-experiment. (Accessed: 10 July 2021).

https://app.powerbi.com/view?r=eyJrIjoiMDBkNWMzY2EtMGV hZC00YWMwLTk2MDYtNjk0MWZhMmE1MTR1Iiwid CI6ImMwMzRjM2I0LWQwMmItNDM2MS04M2YwLT NiMWI5ZWE0MzcwYyIsImMiOjh9 (Accessed: 10 July 2021). 